\title{
The Berlioz-decision of the CJEU provides legal protection for concerned persons in transnational setting, but will it hold in the international area?
}

Berlioz and remedies to ensure effective legal protection, C-682/15

Leo Neve*

Ph.D. student of Erasmus School of Law, Erasmus University at Rotterdam

\begin{abstract}
In the Berlioz judgement ( $C-482 / 15)$, dealing with the transnational exchange of information on request, the CJEU extended the scope of article 51(1) of CFR. The CJEU allows for judicial review of a penalty (article 47 CFR) also in cases where such is necessary for the effective enforcement of the Directive on Administrative Cooperation 2011/16/EU. In reviewing a penalty, the domestic court can and must also review the legality of the underlying order. The concerned party must have access to the basic information about what and why something is requested from him; it is therefore not necessary that he has full access to the actual competent authority letter. The request must be foreseeable and relevant with respect to the taxation of the subject, which the domestic court must ascertain. Based on the Union principle of mutual trust it is not for the domestic court to review the stated facts and circumstances. CFR precludes a restriction on access to a court. It needs to be seen whether this judgement will have spill-over effects exceeding the transnational context of the decision.
\end{abstract}

\section{Introduction}

In the framework of the Directive on administrative cooperation in the field of taxation (DAC), ${ }^{2}$ Berlioz Investment Fund S.A. was ordered by her national competent authority to provide information that had been requested by the competent authority in France. The Directive obliges Luxembourg to assist France and to obtain the answer to questions, or to even to start an investigation in order to obtain the requested information.

* DOI 10.7590/187479817X15095380840384 1874-7981 2017 Review of European Administrative Law

The author is participating in the research programme of the faculty 'Fiscal Autonomy and its Bounderies' (FA), neve@law.eur.nl.

1 Author wishes to thank prof. R.J.G.M. Widdershoven and the anonymous peer-reviewers for their comments on earlier drafts of this article.

2 Council Directive 2011/16/EU of 15 February 2011 on administrative cooperation in the field of taxation and repealing Directive 77/799/EEC, OJ L 64, 11.3.2011, p. 1-12. 
Under national law of Luxembourg, Berlioz is obliged to comply with the request and is not allowed to appeal a decision of a competent authority. Berlioz was fined with a penalty of $€ 150$ ooo for not complying with the information order. The referring Court (Administrative Court) requested a preliminary ruling from the CJEU and wishes to know if Berlioz can rely on article 47 of the Charter of Fundamental Rights of the EU (CFR) to lodge an appeal against the penalty.

In this case note I will provide context and the background of the decision. Mutual administrative assistance between national authorities in the field of taxation is an important policy objective for the functioning of the internal market. The internal market however, is also an area of Freedom, Security and Justice (article 3 TEU) in which the basic rights of subjects are protected by providing effective legal protection in fields covered by Union law (article 19 TEU). Therefore, the exercise of state authority must be balanced with respect for the basic fundamental rights of subjects. After an introduction on the international and transnational principles of mutual administrative assistance with respect to taxation, ${ }^{3}$ I will discuss the questions of the referring court and the ruling of the CJEU on them. In the final section I will look at the relevance of the decision for the international exchange of information. Before coming to concluding remarks (5) I will share my remaining concerns with respect to the influence of the decision on the bilateral exchange of information with States outside the area of the EU.

\subsection{Context and background}

The exchange of information is the preferred method of mutual assistance provided between Member States in the administration of national taxes. Where the tax administration of one State finds that relevant information is detained on the territory of another State, that first State (the requesting State) can ask for assistance from other State (the requested or execution State). The requested State then obtains the information from persons within its territory and forwards the information to the requesting State. The condition for the requested State to be able to provide that information, is often a legal basis in the domestic law of the requested State that allows that State to pierce the obligation of secrecy, in favour of administering taxes in another State. In that respect there are three supranational instruments allowing for such lifting of tax secrecy:

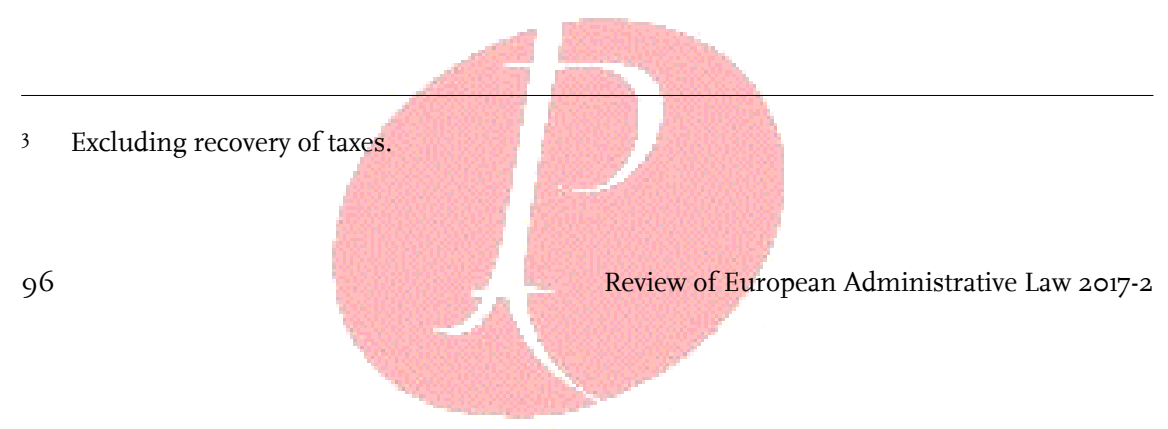


a. The Council Directive 2011/16/EU of 15 February 2011 on administrative Cooperation in the field of taxation 4 (hereinafter: DAC);

$b$. The bilateral agreement for the avoidance of double taxation and the prevention of tax evasion in relation to direct taxes on income and wealth; and

c. An international instrument, exclusively drafted with a view to mutual assistance with respect to the levying and recovery of taxes, and often supplementary to the bilateral treaty, is the joint effort of Council of Europe \& OECD that resulted in the 1988 Convention on Mutual Assistance in Tax matters, as amended by 2010 Protocol. ${ }^{6}$

Almost all Member States of the EU concluded bilateral tax treaties with each other on the basis of the OECD template. The OECD Model Tax Convention (hereinafter: OECD-MTC) is a dynamic Model, adjusted regularly and accompanied by a commentary that serves as a guidance for interpreting the articles of the Model Convention. ${ }^{7}$ Though the Model Convention is dynamic, this does not imply that the bilateral agreements drafted and concluded on the basis of the then available wording of the Model are also dynamic in their application. Amendments to existing tax conventions find their way through additional Protocol provisions and Memoranda of Understanding. This however leads to a plurality of different treaty provisions between the Member States of the EU. It was for this reason that the European Commission introduced the first Mutual Assistance Directive in 1977 in order to harmonize the different provisions for mutual assistance that existed between Member States. ${ }^{8}$ As is stated in the preamble: '... collaboration between tax administrations within the Community should therefore be strengthened in accordance with common principles and rules'. ${ }^{9}$ The common principles and rules refer to the Commentary to article 26 of the OECD MTC, 1977 edition and further adjustments of that Commentary. In the last twenty years the common principles and rules have evolved from a best practice ('should') into an obligation ('shall') especially in regard to carry-

4 Council Directive 2011/16/EU of 15 February 2011 on administrative cooperation in the field of taxation and repealing Directive 77/799/EEC, OJ L 64, 11.3.2011, p. 1-12.

5 The Model Convention that provides a template for most bilateral treaties is the OECD-Model tax convention (for tax conventions between OECD-Member States) and the UN-Model tax convention (for tax conventions between developed and developing countries).

6 www.coe.int/en/web/conventions/full-list/-/conventions/treaty/127 and www.coe.int/en/web/conventions/full-list/-/conventions/treaty/208.

7 For most recent (2014) version, see www.oecd.org/ctp/model-tax-convention-on-income-andon-capital-condensed-version-20745419.htm.

8 Council Directive 77/799/EEC of 19 December 1977 concerning mutual assistance by the competent authorities of the Member States in the field of direct taxation, OJ L 336, 27.12.1977, p. 15 -20.

9 Council Directive 77/799/EEC of 19 December 1977 concerning mutual assistance by the competent authorities of the Member States in the field of direct taxation, OJ L 336 , 27/12/1977 P. $0015-0020$. 
ing out administrative measures in order to obtain requested information. The political driver for that development is the formulation of the so-called Standard for the Exchange of Information on request (hereinafter: EOIR) by the Global Forum on Transparency and Exchange of Information for Tax Purposes (hereinafter: Global Forum). ${ }^{10}$ The Standard found its way in the OECD-MTC in 2005 and was formally endorsed by G20 and OECD members in April 2009." This soft-law Standard became hard-law by an inclusion of that Standard in the 2011 Directive and resulted in an obligation on the Member States to implement the provisions of the Directive. Restrictions on the obligation of a Member State to cooperate are limited. In contrast with the 1977 Directive, the 2011 Directive now states explicitly that the Directive respects fundamental rights and observes the principles which are recognised; in particular by the Charter of Fundamental Rights of the European Union (hereinafter: CFR). ${ }^{12}$ An important element of the mutual assistance procedure is the speed and efficiency of the exchange procedure. ${ }^{13}$ The Directive provides for a six month period in case the requested authority needs to undertake an investigation, but a two month-period in case the information is already available (article 7). The adherence of national authorities that are Global Forum members and identified jurisdictions held to the standard for EOIR are made subject to a peer-review procedure undertaken by the Global Forum. The Global Forum then qualifies the reviewed jurisdictions (after phase 2) as 'complaint', 'largely compliant', 'partially compliant' and 'noncompliant'. ${ }^{14}$

\subsection{Relevant jurisdiction: Luxembourg}

The requested jurisdiction in the case discussed is Luxembourg. Luxembourg's legal framework for the exchange of information is

10 The Global Forum on Transparency and Exchange of Information for Tax Purposes, is a subdivision of the OECD, but composed also of non-OECD member jurisdictions. See www.oecd.org/tax/transparency/. The Global Forum is mandated with the peer-review process of adherence to the global standard for EOIR as endorsed by the OECD.

1 See more on EIOR Standard: Klaus Vogel on Double Taxation Conventions, 4 th edition by Reimer and Rust (ed.), Kluwer Law International, 2015; Xavier Oberson, International Exchange of Information in Tax Matters, Edward Elger, 2015; Danon/Gutmann/Oberson/Pistone (ed.), Modèle de Convention fiscal OCDE concernant le revenu et la fortune, Commentaire, Helbing Lichtenhahn, Editions Francis Lefebvre 2013; Vogel/Lehner (ed.), DBA Doppelbesteuerungsabkommen, Kommentar, 6.Auflage, Verlag C.H. Beck, München 2015.

12 Preambule DAC, no. 28.

13 Preamble 12 of DAC provides: 'Time limits for the provision of information under this Directive should be laid down in order to ensure that the information exchange is timely and thus effective'.

14 See further Leo E.C. Neve, 'The Peer review Process of the Global Forum on Transparency and Exchange of Information for Tax Purposes, a critical assessment on authority and legitimacy', in: Erasmus Law Review, 2017, November, forthcoming. 
heavily influenced by the first $\mathrm{t}^{15}$ and second phase peer-review report of the Global Forum. ${ }^{16}$ The phase 2 report criticizes the legal framework and practice of Luxembourg and attributes an overall qualification of 'non-compliant' to Luxembourg. ${ }^{17}$ The Global Forum developed the so-called 'Terms of Reference' in order to be able to assess adherence to the Standard of EOIR by participants. The Terms of Reference for assessing adherence to the EOIR Standard contain three basic components, broken down into ten essential elements. ${ }^{18}$

Interesting for our analysis is element B 2, stating:

The rights and safeguards (e.g. notification, appeal rights) that apply to persons in the requested jurisdiction should be compatible with effective exchange of information;

The rights and safeguards that apply to persons in the requested jurisdiction should be balanced with the effectiveness of the exchange procedure. The Global Forum in its peer reviews has criticized several countries, including The Netherlands and Luxembourg, for obstructing the efficiency of the process due to administrative and judicial review of the decisions to exchange information. ${ }^{19}$ The Global Forum was, in relation to the Netherlands, especially critical on the administrative procedures such as the notifying of the intention to exchange information, the possibility of reviewing exchange decisions, the length of court proceedings and the right to be heard relating to the disclosure of documents. ${ }^{20}$ In the process of moving towards positive compliance ratings, jurisdictions such as Luxembourg and The Netherlands adjusted their legislative framework, abolished the notification procedure and restricted judicial review. As a consequence, concerned persons (specifically the information owner and the subject of the investigation) have lost valuable legal protection, which are the rights to oppose providing the information. ${ }^{21}$

15 Global Forum on Transparency and Exchange of Information for Tax Purposes Peer Reviews: Luxembourg 2011 PHASE 1 August 2011 (reflecting the legal and regulatory framework as at May 2011).

16 Global Forum on Transparency and Exchange of Information for Tax Purposes Peer Reviews: Luxembourg 2013 PHASE 2: IMPLEMENTATION OF THE STANDARD IN PRACTICE November 2013 (reflecting the legal and regulatory framework as at May 2013), OECD, Paris.

17 See phase 2 Report Luxembourg, para. 14: 'In view of the ratings for each of the essential elements taken in their entirety, the overall rating for Luxembourg is Non-Compliant'.

18 Terms of Reference to Monitor and Review Progress towards Transparency and Exchange of Information for Tax Purposes, OECD, CTPA 2010.

19 Luxembourg has only a judicial appeals procedure and no administrative review procedure.

20 Global Forum on Transparency and Exchange of information for tax purposes, Peer Review Report Combined: Phase 1+ Phase 2, incorporating Phase 2 ratings, The Netherlands, 2013, OECD, Paris, para. 306.

21 In general the taxpayer is obliged to provide information. Also third parties who possess relevant information can be forced to provide information on taxable subjects. 
Countries that have adjusted their national administrative procedures include the Netherlands, which introduced a bill on 25 September 2013 to amend the International Assistance (Levying of Taxes) Act. ${ }^{22}$ This bill proposed abolishing the notification procedure with the intention to restrict the opportunity for judicial review by a court. In his explanatory note to the proposed amendment, the State Secretary of Finance argued that the peer review report recommended abolishing this notification procedure and also that the new EU Directive on Administrative Cooperation (hereinafter referred to as: DAC 1$)^{23}$ did not recognize this procedure. ${ }^{24}$ The amendment also implied that the person would no longer be able to ask for an ex-ante judicial review against the decision to provide the requested information. ${ }^{25}$ Since 1 January 2014 , therefore, the possibility of a judicial review is no longer available in The Netherlands. ${ }^{26}$

Just over a year later, on 25 November 2014, Luxembourg introduced legislation to amend its Act of 31 March 2010. ${ }^{27}$ Under Article 6(1) of the amended legislation, a very limited remedy is available against a request for the exchange of information or against a decision ordering the production of information. ${ }^{28}$ The only available remedy is against the penalty imposed for not complying with the order. ${ }^{29}$ The Luxembourg government, too, argued that the Global Transparency Forum required Luxembourg to make these changes. ${ }^{30}$

In the Cahier de droit fiscal international vol.10oB on The practical protection of taxpayers' fundamental rights of 2015, the International Fiscal Association $(\text { IFA) })^{31}$ also identified Austria, Liechtenstein, Portugal and Switzerland as jurisdictions under pressure from the Global Transparency Forum to remove their existing procedures for notifying taxpayers and their ability to challenge cross-

Wet Internationale bijstand bij de heffing van belastingen.

Directive 2011/16/EU.

Parliamentary Papers II 2013/14, 33753, 3, p. 10-11.

Parliamentary Papers II 2013/14, 33753, 3, p. 34-35.

That statement was repeated during the parliamentary process of approving the bill on the implementation of the automatic exchange of tax rulings, Parliamentary Papers I 2016/17, 34527, B, p. 2.

Mémorial, Recueil de législation, appli.no. 214/27, 27 November 2014, p. 4170.

The single ground for review is the irregularity of the request: art 7 (1) «... Le recours ne peut porter que sur la régularité formelle de la décision d'injonction émise par l'administration fiscale compétente ....».

9 This issue is now decided in CJEU 16-5-2017, Berlioz Investment Fund S.A., C-682/15, ECLI:EU:C:2017:373, where the Cour d'appel has requested a preliminary ruling from the CJEU. See also final decision Cour d'appel Luxembourg of 26 October 2017, no. 36893 Ca.

See Chambre députés, projet loi Doc. parl. 6680; sess. extra ord. 2013-2014 et sess. ord. 20142015 and Peer review report on Luxembourg, phase 2, para. 407 and 436.

For the IFA, see www.ifa.nl/Pages/default.aspx. The IFA is a non-governmental and non-sectoral international organization that offers a forum for experts from different sectors of society to exchange opinions on topics of international taxation with regard for each other's background and responsibilities. 
border exchange of information ('EOI') ${ }^{32}$ With this context as background, we can now look at the decision of the CJEU in Berlioz.

\section{Judgement}

\subsection{Facts and legal frame of the case}

Berlioz Investment Fund SA, a corporation formed under the law of Luxembourg, is a shareholder of its French subsidiary Cofima SA. The subsidiary is able to declare dividends without having to withhold tax under the Parent-Subsidiary Directive 90/435/EEC and its successor Directive 2011/96/EU33 (position taken by Cofima SA), but needs to respect certain conditions (position taken by French authorities) ${ }^{34}$ with respect to the identity of its direct (and indirect) shareholders. Berlioz refers to the Denkavit-decision ${ }^{35}$ where the CJEU has decided that parent companies in member states must be treated equally as domestic parent companies. ${ }^{36}$ After the Denkavit decision of the CJEU, France has introduced anti-avoidance measures in its domestic legislation. ${ }^{37}$ The French competent authority has requested the Luxembourg competent authority to instruct Berlioz to provide the names of their shareholders and the equity-interest each shareholder holds in the company. Berlioz Investment Fund SA refuses to provide the answers to these questions, because it deems the reply not relevant for the tax position in France of Cofima SA, claiming to be itself a Luxembourg entity entitled to withholding tax relief, irrespective of the fiscal residence of its shareholders. Berlioz receives an injunction under the law of Luxembourg to provide the information and is subsequently fined for $€ 250000$ because of a refusal to cooperate. Upon judicial review in the administrative court the fine was subsequently reduced to $€ 150000$.

32 See Baker/Pistone, General Report IFA 2015, 'The Practical Protection of Taxpayers' Fundamental Rights', p. 51.

33 Council Directive 90/435/EEC of 23 July 1990 on the common system of taxation applicable in the case of parent companies and subsidiaries of different Member States, OJ L 225, 20.8.1990, and Council Directive 2011/96/EU of 30 November 2011 on the common system of taxation applicable in the case of parent companies and subsidiaries of different Member States, OJ L 345, 29.12.2011, p. 8-16.

34 The option offered by Article 1(2) of Directive 90/435/EEC of 23 July 1990.

35 Decision CJEU 14 December 2006, case 170/05 (Denkavit France), ECLI:EU:C:2006:783, para. 39 .

36 Note that de Denkavit France decision was issued before the coming into force of the ParentSubsidiary directive 1990 . This directive allows anti-tax avoidance measures. Those measures are the subject of the Eqiom-case C-6/16, CJEU 7-9-2017, ECLI:EU:C:2017:641.

37 These anti-avoidance measures in the Parent-Subsidiary directive have been contested and CJEU has ruled in decision 7-9-2017 C-6/16 (Eqiom) that the shifting of the burden of proof to the beneficiary is precluded under EU law. 


\subsection{Preliminary procedure}

In appeal of the lower court's decision, the administrative court refers the case to the CJEU posing six preliminary questions. The questions relate to issues of

1. The scope of Charter of fundamental rights of the European Union as given in article 51(1) ('provisions of this Charter are addressed to ... the Member States only when they are implementing Union law');

2. Application of article 47 Charter fundamental rights (Right to an effective remedy and to a fair trial);

3. Intensity of judicial review.

These preliminary questions to the CJEU are very important for the judicial protection of the information holder in tax information exchange procedures. The questions have been decided by the Grand Chamber.

\subsubsection{Application of article 51(1) CFR}

The first question relates to the application of the CFR. The preamble to the DAC states in rec. 28 :

This Directive respects the fundamental rights and observes the principles which are recognised in particular by the Charter of Fundamental Rights of the European Union.

Even with the specific reference to the CFR, the opposing Member States France and Luxembourg are of the opinion that due to the fact that the penalty is not foreseen in the Directive, the national law imposing the fine cannot be seen as the implementation of Union law, a basic requirement of article ${ }_{51}$ CFR for the application of the Charter to the Member States..$^{38}$ The CJEU clearly denies this argument (para. 37-39):

37. While it refers to the measures aimed at gathering information that exist under national law, Directive 2011/16 thus requires Member States to take the necessary measures to obtain the requested information in a way that is consistent with their obligations in relation to the exchange of information.

38. It must be noted that, in order to ensure that the directive has practical effect, those measures must include arrangements, such as the pecuniary penalty at issue in the main proceedings, which ensure that there is sufficient incentive for the relevant person to respond to tax authorities' requests, and thereby enable

38 This seems to be a quiet reference to C-418/11 (Texdata Software), ECLI:EU:C:2013:588. 
the requested authority to fulfil its obligations towards the requesting authority.

39. The fact that Directive 2011/16 does not make express provision for penalties to be imposed does not mean that penalties cannot be regarded as involving the implementation of that directive and, consequently, falling within the scope of EU law.

The Court refers to the fact that the DAC imposes certain obligations on Member States, more in particular to take 'measures aimed at gathering information' (article 18 DAC) and the 'necessary measures to ensure smooth operation of the administrative cooperation agreements' (article 22(1) DAC). Therefore the pecuniary penalties imposed by the Luxembourg authorities are 'within the scope of Union law' ${ }^{39}$ The CJEU and the A-G Wathelet hereby refer to the decision in Åkerberg Fransson where CJEU declared:

It follows that tax penalties and criminal proceedings for tax evasion, such as those to which the defendant in the main proceedings has been or is subject because the information concerning VAT that was provided was false, constitute implementation of Articles 2, 250(1) and 273 of Directive 2006/112 (previously Articles 2 and 22 of the Sixth Directive) and of Article 325 TFEU and, therefore, of European Union law, for the purposes of Article 51(1) of the Charter..$^{4}$

\subsubsection{Judicial review}

The second issue before the CJEU relates to judicial review of the underlying order that initiated the fine. Berlioz questions the legality of the underlying order that required her to produce the requested information. She is of the opinion that some of the questions posed have no connection with the levying of taxes. But is she in this respect entitled to an effective remedy on the ground of Article 47 CFR? do some conditions have to be fulfilled before Article 47 is applicable, or is it applicable irrespective of which rights and freedoms are at stake? The point here is that the DAC does not confer any rights on individuals. It is derived from the earlier case Sabou ${ }^{41}$ that the Directive covers only the exchange of information between competent authorities and confers only rights and obligations on the Member States. The Directive does not oblige Member States to give the taxpayer a hearing. (Sabou, para. 30 to 36). In the opinion of the CJEU that does not mean, however, that an individual has

\footnotetext{
39 Judgement, para. 39.

40 Decision CJEU 26-2-2013, C-617/10 (Åkerberg Fransson), ECLI:EU:C:2013:105, para. 27.

41 Decision CJEU 22-10-2013, C-276/12 (Sabou), ECLI:EU:C:2013:678.
} 
no right to defend his position before a tribunal in accordance with article 47 of CFR (para.49):

fundamental rights guaranteed in the legal order of the EU are applicable in all situations governed by EU law and the applicability of EU law entails applicability of fundamental rights guaranteed by the Charter.

The Court refers to earlier judgements when he makes the statement that it should be born in mind that (rec. 51):

protection against arbitrary or disproportionate intervention by public authorities in the sphere of the private activities of any natural or legal person constitutes a general principle of EU law.

The protection may be invoked by a relevant person in respect of a measure adversely affecting him, such as the information order and the penalty at issue and that person can rely on a right guaranteed by EU law, within the meaning of article 47 of the Charter, giving him the right to an effective remedy (para. 52 ). With respect to the subject matter of the right, the Court makes a distinction between a remedy against the penalty or a challenge of the information order on which the penalty is based and decides that in order to satisfy the requirement of Article 47 CFR, the national court must be able to examine the legality of that information order as well.

\subsubsection{Foreseeably relevant}

The third issue, which is the subject of the fourth question of the referring court, is whether it is a condition that the question of the requesting State is of 'foreseeable relevance' for the assessment of the subject. The referring court in fact wishes to know if the information request must be given 'recognition' without scrutiny of the relevant legal basis. ${ }^{42}$ This issue questions the legality of the information order addressed by a Member State to a relevant person. The CJEU opines that the words 'foreseeably relevant' describe a necessary characteristic of the requested information, rec. 63:

It is apparent from the wording of those provisions that the words 'foreseeably relevant' describe a necessary characteristic of the requested information. The obligation imposed on the requested authority under Article 5 of Directive 2011/16 to cooperate with the

42 In the Referenzentscheidungsmodell of Sydow the requested State must recognize the legitimacy of the request under its national law. Gernot Sydow, Verwaltungskooperation in der Europäischen Union, Mohr Siebeck 2004, par. 9 on Referenzentscheidungsmodell. 
requesting authority does not extend to the communication of information that is considered not to have that characteristic.

The obligation to cooperate with the requesting authority is limited to information that is considered to have relevance. That relevance must be foreseeable. The information should be able to clear a certain relationship or a certain fact that may be potentially relevant. The national court does not have to investigate whether the question is relevant, because that requires an in-depth analysis of the facts, for which the court is not equipped and which would cost a lot of time. Given the urgency of any reply to a request, the national court only has to consider if the questions may be relevant for the requesting authority.

\subsubsection{Intensity of judicial review}

The issue of the legality of the request is addressed in the third and fifth questions of the referring court. Having seen that the 'foreseeable relevance' of the question is a condition that must be fulfilled, the third and fifth questions relate to the intensity of the judicial review of that condition. The CJEU decided that, in the context of the review of the penalty, the national court has unlimited jurisdiction to review the legality of the information order (para. 82). That review is not limited to the procedural regularity of the request, but the national court must verify that the condition of foreseeable relevance has been satisfied in all its aspects, including the limitations of article 17 DAC. The scope of the review is however limited, because the cooperation between tax authorities is based on rules intended to create confidence between Member States. The requested authority must trust the requesting authority. It must assume that the request for information complies with the requirements of the domestic law of the requesting authority and that the request is necessary for the purposes of its investigation. ${ }^{43}$ The review of the request by the requested authority is limited to the discretion exercised by the requesting authority. The review by the court is therefore limited to a verification whether the information sought is not devoid of any foreseeable relevance to the investigation, para. 86:

Consequently, the courts must merely verify that the information order is based on a sufficiently reasoned request by the requesting authority concerning information that is not - manifestly - devoid of any foreseeable relevance having regard, on the one hand, to the taxpayer concerned and to any third party who is being asked to provide the information and, on the other hand, to the tax purpose being pursued.

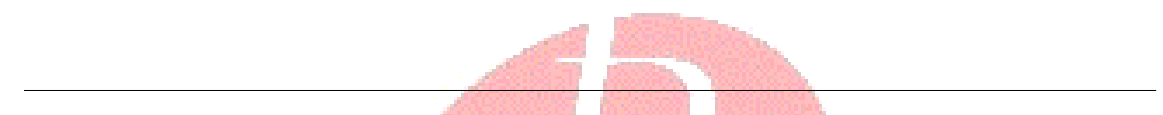

43 Judgement, para. 77. 
It is therefore the task of the requested authority to verify, not only the procedural regularity, but in principle (para. 89):

to satisfy itself that the information sought is not devoid of any foreseeable relevance having regard to the identity of the taxpayer concerned and that of any third party asked to provide the information, and to the requirements of the tax investigation concerned.

The national court has thus jurisdiction to vary the penalty imposed and to review the legality of that information order. In that respect (rec. 89):

the courts review is limited to verification that the requested information manifestly has no such relevance.

\subsubsection{Competent Authority Letter}

The final issue, the sixth question, is about the content of the case file. The question here is whether, in the context of judicial review, the court of the requested Member State must have access to the request for information (the Competent Authority Letter, hereinafter CAL) and the additional question is whether that document must also be communicated to the concerned person in that State or whether access to that document may be refused on grounds of confidentiality. Basically the requested State must keep the communication confidential with the requesting State. Article 16 DAC provides therefore that the communication shall be covered by the obligation of official secrecy and will enjoy the protection equivalent to similar information under the national law of the Member State which received it. National treatment is thereby the norm. National treatment can differ between the Member States. The DAC does not prescribe a certain attitude.

The law in Luxembourg provides that the requested person must know what is requested from him (and not the reason why). That law does not specify that a reason must be given, nor that the foreseeable relevance of the questions must be disclosed.

In that respect the CJEU finds that the information order did not provide sufficient information in order to establish the foreseeable relevance of the questions. Therefore, the complete CAL must be brought to the tribunal hearing the case against the pecuniary penalty, as otherwise it would be unable to carry out the review of legality required by Article 47 of the Charter. The CJEU (para. 101):

Consequently, the answer to the sixth question is that the second paragraph of Article 47 of the Charter must be interpreted as meaning that, in the context of a judicial review by a court of the requested Member State, that court must have access to the request for information addressed to the requested Member State by the requesting 
Member State. The relevant person does not, however, have a right of access to the whole of that request for information, which is to remain a secret document in accordance with Article 16 of Directive 2011/16. In order for that person to be given a full hearing of his case in relation to the lack of any foreseeable relevance of the requested information, it is sufficient, in principle, that he be in possession of the information referred to in Article 20(2) of that directive.

\subsection{Conclusions Berlioz}

A penalty imposed to give effect to an obligation based on (but not written into) a Directive is an act within the scope of Union law and implies that the CFR is applicable. The national court has unlimited jurisdiction to review the legality of the information order and can vary the penalty. The foreseeably relevance of the request is an anchoring principle. The scope of the review of the foreseeably relevance of the request is limited, given the time constraints of the inquiry, also with regard to principle of confidence and the fact that information which has no relevance cannot be used against the taxpayer. The Competent Authority Letter need not to be disclosed, if the concerned party is otherwise informed of the information that is requested and the purpose for which it is requested. The referring court has jurisdiction to review the legality of the request. In his final decision the Cour d'Appel, taking into account the ruling of the CJEU, concluded that the competent authority has not reviewed the foreseeably relevance of the request and cancelled the injunction. ${ }^{44}$

\section{Relevance of the decision}

Berlioz is an important decision for the exchange of information under principles of European administrative law. The European Union is, because of the interconnection between the European and national legal orders, referred to as an 'integrated or composite' legal order. Because national law is employed to implement Union law the European administration is often referred to as a 'shared administration'. ${ }^{45}$ In this shared administration, the cooperation between Member States (horizontal) and between Commission and Member States (vertical) is based on the principle of sincere cooperation, article 4(3) TEU. And in this shared administration, the citizens of the EU have rights and Member States have the obligation (article 19 TEU) to provide remedies sufficient to ensure effective legal protection in the fields covered by Union law. Under

44 Final decision Cour d'appel Luxembourg of 26 October 2017, no. $36893 \mathrm{Ca}$.

45 See further J.H. Jans, S.Prechal and R.J.G.M. Widdershoven, Europeanisation of Public Law, 2nd ed. European Law Publishing, Groningen 2015, p. 7 with further references. 
the pressure of the Global Forum the Member State Luxembourg had cancelled the protection of citizens against exchange of information with another Member State, which is against the treaty (constitutional) right to an effective remedy. The global norm of EOIR is confronted with the normative framework of the EU legal order. Citizens' rights prevail.

\subsection{International and transnational mutual assistance}

The transnational obligation of Member States to provide each other mutual assistance in the levying of taxes is based on the Directive (DAC). The directive provides for coordination at administrative level due to the obligation of a Member State to respond to a request. However, there is also a strict separation between the jurisdictions of the national courts, meaning that cooperation between national authorities on the basis of the Directive is adjudicated in the jurisdiction that takes the final decision. Irregularities in the process of an information request in the requested (executing) State cannot be adjudicated by a court in the requesting State that takes the final decision. The question then is whether a concerned party in the executing State (often the information holder) has standing in his State against the order to produce the information. This question is relevant because the request for information is of a preparatory nature for decisions that will be taken in the requesting State in relation to the taxable subject (as was the case in $S a b o u^{46}$ ). Berlioz deals only with the rights and remedies available to the concerned party in the requested state. The referring Court asks itself whether the information request is (in the terminology of EU administrative law) in fact an authorisation with automatic transnational effect or whether that effect is subject to verification by the national authority (leading to potential instability of the transnational act). ${ }^{47}$ If the act is self-executing, the host country is prohibited from carrying out any verification of the validity of the act itself. ${ }^{48}$ The decision paradigm is different in case the host country must undertake a verification as to the legitimacy, which can result in a recognition or a refusal and thereby lead to a potential instability of the transnational effect. The latter will however give more weight to the interests of the host country.

46 Decision CJEU 22-10-2013, C-276/12 (Sabou), ECLI:EU:C:2013:678.

47 See Gernot Sydow, Verwaltungskooperation in der Europäischen Union, Mohr Siebeck 2004, par. 9 on Referenzentscheidungsmodell.

48 See opinion A-G Bobek in C-298/16 (Ispas) where the A-G questions the self-executing character of an E 101-declaration in case of fraud. 


\subsection{Article $19 \mathrm{TEU}$}

Article 19 of the TEU instructs Member States to ensure effective legal protection in a field covered by Union law. The case of Berlioz is an illustrative example of the application of that rule. The constitutional nature of article 19 TEU may conflict with the principle of procedural autonomy in Member States. ${ }^{49}$ In the legal architecture of the EU, judicial enforcement of EU law belongs firstly and mainly to national courts. And EU law is implemented and enforced mainly through national administrative institutions and decisions, which are subject to the jurisdiction of national courts. Therefore, EU law has put constraints on national adjudication to ensure that the primacy of EU law is secured. National courts are also the first in line for the execution of rights given to subjects under the European Convention for the protection of Human Rights (ECHR). Therefore, great importance is given to the possibility for subjects to claim judicial protection and to present their case before an impartial and independent tribunal. Article 6 of the ECHR and article 47 of the EU Charter of Fundamental Rights (CFR) provide for the right of subjects to address a court to claim effective legal protection in case protected rights have been infringed.

\subsection{The scope of Article 51(1) CFR}

The provisions of the CFR are addressed to Member States 'only when they are implementing Union law'. The provision is designed to clarify that under the CFR the Member States are only bound to respect fundamental rights in a cases governed by Union law. ${ }^{50}$ The leading case on the meaning of the phrase 'Member States only when they are implementing Union law' is the judgement of the CJEU of 26 February 2013 in Case C-617/10 ( $\AA k$ lagaren v. Hans Akerberg Fransson). The case concerned the question whether article 51 was satisfied so as to entitle an accused to invoke the ne bis in idem principle, as protected by article 50 of the CFR. Criminal proceedings were instigated against Mr Åkerberg for a breach of Swedish VAT law, while infractions had already been dealt with by Swedish administrative authorities. A series of Member States and the EU Commission questioned the admissibility of the order for a reference. The Court considered that the situation was 'governed by European Union law' because the tax penalties and criminal proceedings Mr. Åkerberg was subjected to are 'connected in part' to breaches of his obligation to pay VAT. The Court took article 235 TFEU into consideration and considered that VAT fraud affects the financial interests of the European Union; thus tax

49 See J-B Auby, About Europeanization of Domestic Judicial Review, REALaw; Vol. 7, issue 2, $19-34[2014]$.

50 Article 6(2) TEU and Text of Explanatory Note on article 51. 
penalties and criminal prosecution to counter illegal activities affecting European Union interests, constitute implementation of Union law and are within the scope of article 51(1) CFR. Also in COM v. Greece $e^{51}$ and Bonda $a^{52}$ the protection of EU interests were at stake. In Texdata Software ${ }^{53}$ the Directive left it to the Member States to determine the appropriate penalties in order to ensure compliance with disclosure obligations. In Berlioz there is no reference in the Directive to an effective enforcement of obligations for the concerned persons. The scope of Union law here is directly related to the obligation of the Member State to ensure that the Directive has practical effect, so that the implementation must include arrangements which ensure that there is sufficient incentive for the relevant person to respond to the authorities' requests. The scope of article 51(1) CFR however is not finally settled. A-G Bobek in his conclusion in case Ispas ${ }^{54}$ made a distinction between three scenarios for the application of article 51(1) CFR. The first scenario concerns the direct application of Union law, which poses no special problems. In the second scenario, the indirect application is of more concern. The third scenario, the derogation scenario, is where national law derogates from Union law. In the indirect application scenario national and European rules apply. The pertinent issue identified by the A-G Bobek is the proximity between the original EU law obligation and its national (non-)realisation or, put differently, the degree of specificity of the EU law rule or obligation at issue. ${ }^{55}$ What is exactly meant by implementing EU law obligations? The response is not so difficult with respect to substantive provisions of EU law, but more complicated when it comes to procedural elements. The applicability of EU fundamental rights requires a solid degree of connection. ${ }^{56}$ It should be noted here that the original law of 2010 was meant to implement the transparency Standard to which Luxembourg had committed itself in March 2009, especially with respect to banking information. The amendments of 2014 were also aimed at the implementation of the Directive 2011/16. Thus, there was a specific connection between the national procedural rules and the DAC.

With the CFR being applicable, this opens the door to the application of article 47, the basic article providing for a right to an effective remedy, being a general principle of EU law. This right is an essential requirement for ensuring the rule of law within the Union (art 2 TEU) as recognized in Les Verts ${ }^{57}$ and further outlined in Union de Pequeños Agricultores v. Council..$^{8}$ But note that as

51 Decision CJEU 21-9-1989, C-68/88 (COM v. Greece), ECLI:EU:C:1989:339.

52 Decision CJEU, Grand Chamber, 5-6-2012, C-489/10 (Bonda), ECLI:EU:C:2012:319.

53 Decision CJEU 26-9-2013, C-418/11 (Texdata Software), ECLI:EU:C:2013:588.

54 Opinion A-G Bobek 7-9-2017, C-298/16 (Ispas), ECLI:EU:C:2017:650.

55 Opinion A-G Bobek, rec. 33.

56 See also decision CJEU 6-3-2014, C-206/13 (Siragusa), ECLI:EU:C:2014:126, para. 24.

57 Decision CJEU 23-4-1986, C-294/83 (Les Verts), ECLI:EU:C:1986:166.

58 Decision CJEU 25-7-2002, C-50/00 (Union de Pequeños Agricultores v. Council), ECLI:EU:C:2002:462. 
a general principle, the right to an effective remedy is not only depending upon article 51 CFR. In Sabou ${ }^{59}$ the CJEU recognized that the CFR was not yet applicable, but that the Court still has jurisdiction to decide the case. Para. 28:

It is clear from the case-law of the Court that the rights of the defence, which include the right to be heard, are among the fundamental rights that form an integral part of the European Union legal order. Where national legislation comes within the scope of European Union law, the Court, when requested to give a preliminary ruling, must provide all the criteria of interpretation required by the national court to determine whether that legislation is compatible with fundamental rights. (references to decided case law omitted).

It should be mentioned here that the right to an effective judicial remedy is an accessory right, in that it requires another right arising from EU law to be protected before it will become operative. That right can be a protection from a penalty or fine, but also a right to be protected from interference with private and family life, home and correspondence and a right to data protection. Protection against interference with private life is under circumstances applicable to legal entities, but a right to data protection is restricted to natural persons. Exchange of information cases often refer to an exchange of data about private persons and this data is therefore often protected against interference by a foreign authority. The CJEU has confirmed that a decision to exchange information is a decision adversely affecting the interests of a person, whether that person is the subject of the investigation or an otherwise concerned party. ${ }^{60}$ That person has the right to be heard and to express his views. And ultimately that person has a right of judicial review, whether the national law of that party provides for a review process or not. Member States are thus under an obligation to create remedies additional to those already existing under their national procedural law, if it is necessary to guarantee the relation between rights and remedies under EU law. A Fine example of that is the cases of Borelli ${ }^{61}$ and Factortame. ${ }^{62}$ The direct effect of Union law requires that conflicting national rules are to be set aside and therefore the limitation of access to court in the Luxembourg law is set aside in Berlioz.

\footnotetext{
59 Decision CJEU 22-10-2013, C-276/12 (Sabou), ECLI:EU:C:2013:678.

6o Sabou, C-276/12, para. 38 and decision CJEU 18-12-2008, C-349/07 (Sopropé), ECLI:EU:C:2008:746, para. 37.

61 Decision CJEU 3-12-1992, C-97/91 (Oleificio Borelli/Commission), ECLI:EU:C:1992:491.

62 Decision CJEU 5-3-1996, C-48/93 (Factortame), ECLI:EU:C:1996:79.
} 


\subsection{Effective remedy Article 47 CFR}

The ruling of the CJEU in Berlioz, requiring 'recognition' in national law of a foreign act, is understandable because the transnational effect of the information request (the obligation to cooperate) is not automatically provided. The act of 'recognition' requires the national authority to verify if the conditions for execution are fulfilled. The principle of proportionality requires a balancing of interests, which review is the task of the national competent authority and ultimately of the domestic court.

It is necessary here to make a firm distinction between the taxpayer who is the subject of the investigation and the concerned party who is asked to the provide information. For the taxpayer the investigation is preparatory to the final decision on the assessment. He cannot challenge a preparatory measure. But a concerned person who is asked to provide information in the context of an exchange of information between national tax administrations pursuant to DAC is entitled to challenge the legality of that decision (Berlioz para. 59).

\subsection{Scope of review}

Up to 2005 the official text and Commentary to article 26 of OECD MTC referred to information that was 'necessary' for carrying out the provisions of the Convention and domestic laws. The first Mutual Assistance Directive (77/799/EEC)(hereinafter:MAD) requested information to be exchanged that 'may enable' the competent authorities to effect a correct assessment of taxes on income and on capital. This was already a deviation from the OECD norm of 'necessary information'. The 2011 Directive (replacing the MAD) brings back the foreseeable relevance wording, replacing necessity. We will need to observe here that the ECHR (article 8(2)) requests an infringement to be in accordance with the law and 'necessary' in a democratic society, in order to be acceptable, conditioned by proportionality and subsidiarity. This means that the infringement in private life must have a basis in the law and not go further than necessary, while respecting less intrusive measures. The limitation of the burden to comply is based on proportionality (see article $17 \mathrm{DAC})$. A requested State does not have to take measures that the requesting State itself cannot fulfil (principle of reciprocity), the requesting State must have exhausted its own national resources and means (subsidiarity) before moving to international assistance and finally the questions must have foreseeable relevance. All these limitations are case-sensitive.

\subsubsection{Review of legality}

There has been questioning in the comments on the Berlioz judgement, whether the ruling of the CJEU is also relevant in case there has 
been an order to provide information, without a penalty. ${ }^{63}$ Nothing in the wording of the ruling of the CJEU indicates that a penalty is a necessary requisite. In para. 99 the CJEU provides guidance also for review of the order without there being a penalty. The CJEU puts the legality review of the information order at the same level as the review of the legality of the penalty.

\subsection{Competent Authority Letter}

The OECD-Commentary to the article 26 OECD-MTC (para. 11) provides that the confidentiality rules apply also to the Competent Authority Letter (CAL). And also that the requested state, in general, can disclose the minimum information contained in the CAL, (but not the letter itself) that is necessary for the requested state to obtain or provide the requested information to the requesting state, without frustrating the efforts of the requesting State. The OECD-Commentary adds that if court proceedings under the domestic laws of the requested State necessitate the disclosure of the Competent Authority Letter itself, the competent authority may disclose such a letter unless the requesting State specifies otherwise.

The matter affects the adversarial principle. The link between the requested information and the tax objective pursued by the requesting authority is developed in the CAL. The person concerned needs to know which information is requested and for what purpose. The law in Luxembourg however provides only that the requested person must know what information should be provided by him and not the reason why. The law does not specify that a reason must be given, nor that the foreseeable relevance of the questions must be disclosed.

The guarantee of an effective remedy requires as a minimum that the independent appeals authority must be informed of the reasons grounding the contested decision, even if such reasons are not publicly available. A-G Wathelet refers in his conclusion to the conclusion of A-G Bot in case $Z Z^{64}$ that the tribunal must have access to all information even where an allegation of a threat to national security is made (para.92). This implies a full disclosure to the tribunal, but is restricted to the task of the tribunal. That task is to establish the foreseeable relevance of the questions for the taxation interest of the requesting State. Full disclosure of the CAL is therefore not necessary if that relevance can be established from the information given by the requested authority. Whether the CAL will be disclosed to the litigating party is subject to the discretion of the tribunal in those cases where the defendant objects to the disclosure. Even if the DAC and the Commentary provide that the CAL will not be disclosed, a sealing of that letter or otherwise limiting the access of the litigant to the letter

63 See J.A.R. van Eijsden, note in $B N B$ 2017/178.

64 CJEU, C-300/11 (ZZ), EU:C:2012:563. 
is subject to a balancing of the interests at stake. The interest of the competent authority in preserving the confidentiality of the communication with the competent authority of the requesting State must be balanced with the interests of the litigant in a full disclosure of the letter. The adversarial trial principle requires an equality of arms. Only if the interests of State outweigh the interests of the litigant considerably, can the disclosure be restricted. ${ }^{65}$ But the tribunal hearing the case should always articulate the reasons that would support a sealing of the communication. It will be an abuse of discretion if the tribunal fails to weigh openly the interests that are involved. Therefore, in general, one can say that there are only reasons for limiting party access to the correspondence if the requesting State has expressed its desire to keep the correspondence confidential. The competent authority of the requested State should then give the tribunal reasons for his refusal to give the litigant access to the whole file. The role of the court is, in most cases, at least to articulate any reasons that would support a restriction or explain why it made the decision to restrict. The explicit findings by the court, whereby the court takes in consideration the entire case specific balance of the right of access against interests favouring non-disclosure, must be with a level of detail that will allow for a review by appeal. The result is often the statement that 'there is a substantial probability that the investigation will be compromised if the Letter is disclosed'. The Dutch Raad van State, appeals court for administrative law, in general allows the sealing of the CAL with the statement 'in the interest of the relations of the Netherlands with other States and given the economic and financial interests of the Netherlands'. ${ }^{66}$ The CJEU in Berlioz has now made clear that the full request (CAL) should be provided to the adjudicating court, contrary to the OECD commentary.

\subsection{Notification requirement}

The notification requirement is in my opinion a necessary element of procedural justice in the legal protection of the taxpayer and of the concerned party. The notification is an essential element of good governance as it allows the concerned person to present his interests especially with respect to the proportionality aspect of the necessity test. The legal requirement of balancing interests of State and concerned persons require a standing of that person in the process of adjudication and judicialisation. The European Court of Human Rights (hereinafter: ECtHR) in his decision M.N. and Others v. San Marino ${ }^{67}$ stressed the importance of adequate guarantees against arbitrariness,

65 ECtHR judgement 16-2-2000, 28901/95 (Rowe and Davies), para. 61: 'However, only such measures restricting the rights of the defence which are strictly necessary are permissible under Article $6 \rrbracket 1^{\prime}$.

66 RVS 31-8-2009 (Othymia), ECLI:NL:RVS:2010:BM7770.

67 ECtHR 7-7-2015, Case of M.N. and others v. San Marino, appli.no. 28005/12, para. 73 . 
including the possibility of effective control of the measure (spontaneous exchange of information for tax purposes) at issue.

\section{Two remaining concerns}

I have two concerns with respect to the judgement. The first one is the plurality of national treatment over a more uniform treatment. My second concern relates to the emphasis on mutual trust in dealings between Member States.

\subsection{No uniform national treatment}

The decision in Berlioz relates to the exchange of information between Member States of the EU on the basis of DAC. The CJEU applies the CFR as the basis of his decision and Member States should do the same. In another case, the Tribunal administrative of Luxembourg was asked in 2015 to decide on the exchange of information between Luxembourg and Argentina (requesting State). ${ }^{68}$ The tribunal stayed the procedure, requesting the parties to the litigation for comments on the preliminary ruling request of the administrative court in the case of Berlioz. ${ }^{6}$ No decision in that case has yet been published. It means that a concerned person can claim protection under the CFR in case the legal basis of the information request is in the Directive. If the legal basis is in a bilateral treaty, there will not be an EU-influence of the defence rights of the concerned person. For states that are members of the Council of Europe, ${ }^{70}$ the European Convention for the protection of Human Rights and fundamental freedoms (ECHR) is applicable..$^{11}$ Article 6 of that Convention is the gateway to judicial protection. But the application of article 6 is restricted to 'the determination of his civil rights and obligations or of any criminal charge against him'. A fine for not complying with a request for information is a penalty with a punitive character and thus of criminal nature. ${ }^{72}$ Tax litigation, on substantive tax law, is excluded from the application of article 6 ECHR. However, in the case of Sabou, the CJEU did not need the assistance of the CFR to conclude that Sabou had standing, as it was based on 'general principles' of European law. The CJEU concluded (38):

68 Tribunal administratif 18-12-2015, no. 36985, not yet decided.

69 At the time of writing this case-note the referenced case was still pending.

70 www.coe.int. The Council of Europe is the continent's leading human rights organisation. It includes 47 member states, 28 of which are members of the European Union.

$71 \quad$ ETS no. 5 Rome 4.XI.1950.

72 ECtHR decision 24-2-1994, 12547/86 (Bendenoum v. France), para. 47. 
The Court has previously ruled that observance of the rights of the defence is a general principle of European Union law which applies where the authorities are minded to adopt a measure which will adversely affect an individual (see Sopropé, paragraph 36). In accordance with that principle, the addressees of decisions which significantly affect their interests must therefore be placed in a position in which they can effectively make known their views as regards the information on which the authorities intend to base their decision (see, inter alia, C-32/95 P Commission v. Lisrestal and Others [1996] ECR I-5373, paragraph 21, and Sopropé, paragraph 37). The authorities of the Member States are subject to that obligation when they take decisions which come within the scope of European Union law, even though the European Union legislation applicable does not expressly provide for such a procedural requirement (see Sopropé, paragraph 38, and Case C-383/13 PPU G and R [2013] ECR, paragraph 35).

The question is therefore whether general principles of law can be found in other jurisdictions as well. It is clear that any legal protection against information exchange based on a bilateral treaty between Luxembourg and Argentina cannot be based on European principles. But can a resident of Luxembourg, as a concerned person involved in this procedure, claim in Luxembourg a general principle that allows him to access the court to protect his interests? This question brings us to the heart of the conflict between private interests and state authority. Irrespective of positive words in a statute requiring a hearing or access to a court, the scope of the judicial element in natural justice takes precedence. In the process of balancing the interests of State and individual one must recognize process rights in the adjudication procedure. Procedural justice may lead to substantial justice of the outcome and thereby increase the legitimacy of State's action. Procedural rules also help to attain accurate decisions on the substance of the case. Procedural rules help protect human dignity.

Whether or not the involved person can claim constitutional protection against an infringement by the authorities of his fundamental rights is a matter that will be decided differently in the plurality of administrative protection in the various countries. In our example of Luxembourg, there will be no legal protection available with respect to an information request from Argentina, because the information holder will have no recourse to the CFR. However he could address the ECtHR, a situation similar to the decided case of Othymia Investments BV. ${ }^{73}$ In Othymia the ECtHR said it is

prepared to accept that there has been interference with the applicant company's rights under Article 8 (see Société Colas Est and Others v. France, no. 37971/97, $\int 42$, ECHR 2002-III, and Bernh Larsen Holding AS and Others v. Norway, no. 24117/o8, ( 106, 14 March 2013). Such interference will constitute a violation of that

73 ECtHR decision 16-6-2015 (Othymia Investments BV), appli.no. 75292/10. 
Article unless it is 'in accordance with the law', pursues one or more of the 'legitimate aims' set out in the second paragraph, and is 'necessary in a democratic society. ${ }^{74}$

The legitimate aim that the ECtHR accepts in Othymia is the EU's internal market: 'the economies of the European Union Member States forming a unified whole'. ${ }^{75}$ With respect to the necessity condition, the ECtHR takes in consideration the Sabou judgement of the CJEU and accepts in Othymia that the subject has no rights in the investigation stage of the process, even if the 'applicant is not the 'taxpayer' and therefore not directly concerned by the Sabou judgment. ${ }^{76}$ This part of the decision has been subject to severe criticism, because it leaves the concerned party, information holder, without judicial protection in his home State. The CJEU in Berlioz has corrected that by providing defence rights to the concerned party. An element of the necessity test is also a review of the adherence to the proportionality-principle. In deciding whether the infringement of a basic right is justified, the person must be heard and be able to give his view. This means that he ultimately must have access to a court to balance the interest of Argentina (and Luxembourg) in the exchange of information against his individual interest not to have his personal information divulged to a foreign authority.

In the circumstances of that case the taxable subject of the investigation may have grounds in litigation in Argentina to oppose the use of the information from Luxembourg. The multi-jurisdictional nature of the information exchange may and often will, diminish the protection of individual rights and possibilities for effective judicial review. A judge in Argentina will not be able to validate the legality of the information received from Luxembourg. This therefore requires procedural rules in the international instrument that is used as a basis for the exchange. It may also require that the executing State does not treat the decision to exchange information as a 'preparatory act' (as ECtHR did in Othymia) with respect to the final decision on the assessment. ${ }^{77}$

These international instruments (Double Tax Conventions and Multilateral Convention) often do not provide for an ex-ante review of the legality for information exchange. The multilateral 1988 Convention on Mutual Assistance in Tax matters, as amended by 2010 Protocol, does not provide for process rights of involved persons. ${ }^{78}$ In the Sabou case the CJEU ruled (para. 49):

\footnotetext{
74 Para. 37.

75 Para. 41.

76 Para. 44 .

77 See Herwig C.H. Hofmann, 'Decision making in EU Administrative Law-The problem of composite procedures', 61 Admin. L. Rev. 199, 222(2009), who proposes review in form of a declaratory action of factual conduct.

78 www.coe.int/en/web/conventions/full-list/-/conventions/treaty/127 and www.coe.int/en/web/conventions/full-list/-/conventions/treaty/208.
} 
In those circumstances, only national laws can lay down the relevant rules. The taxpayer may challenge the information concerning him conveyed to the tax authorities of the requesting Member State in accordance with the rules and procedures applicable in the Member State in question.

The CJEU gives priority to the plurality of national administrative law over a direction towards approximation of national rules under common European umbrella. The ruling of the CJEU in Sabou violates the equivalent protection treatment of concerned persons. It could make a big difference for the taxpayer whether the information order has been tested in advance in the executing State for legality or whether his home court has to make such a determination.

\subsection{Mutual trust}

The CJEU places, because the EU is an integrated administration, great emphasis on the duty of sincere cooperation between Member States (at horizontal level) and between Member States and Commission (at vertical level) and the mutual trust element derived therefrom. The mutual trust between Member States restricts the intensity of the review of the national courts. The national court must accept that a request is deemed to be foreseeably relevant in case the reason of the request and the persons involved are stated in the request. The national court has no full jurisdiction and may not verify if the stated facts are true, it must accept the statements with respect to taxes covered and the reciprocity and exhaustion of national measures. ${ }^{79}$

The duty of sincere cooperation does not exist in the strict sense between members of the Council of Europe (to which the ECHR applies) and between tax convention partners from jurisdictions outside the European Union. Even if it can be deemed that the members of the Council of Europe will all apply the principles of the ECHR, such cannot be deemed to be the case between other tax convention partners. Is the fact that a concerned person is restricted in adhering a court, for review of a decision to exchange information, an element that is incompatible with the duty of a Contracting State to interpret and apply a bilateral treaty in a manner consistent with fundamental rights? What is exactly meant with exceptional situations that hinder Member States in verifying whether a Member State has actually observed fundamental rights? ${ }^{80}$ When is

See for cases decided by ECtHR on restricted jurisdiction of the court, decision 22-11-1995 (Bryan v. UK), appli.no. 19178/91, decision 18-1-2001 (Chapman v. UK), appli.no. 27238/95 and decision 18-01-2001 (Jane Smith), appli.no. 25154/94.

80 CJEU, Opinion 2/13 of 18 December 2014 on the draft agreement providing for the accession of the European Union to the European Convention on Human Rights, pt. 192. 
the presumption conclusive ${ }^{81}$ In contrast with the opinion 2/13 of the CJEU, the ECtHR concluded, on the basis of his Bosphorus judgement, that the presumption of adherence to fundamental rights is in principle a rebuttable presumption. ${ }^{82}$ For the principle to be rebuttable, it needs that adherence to fundamental rights is manifestly deficient.

\section{Concluding remarks}

With the decision in Berlioz the CJEU has strengthened the legal protection of the concerned party in exchange of information procedures on the basis of the Directive (DAC). The CJEU corrects in fact the limitations established by the ECtHR in Othymia (request is of preparatory nature for the final decision of the requesting State) and decides that the enforcement of obligations under a Directive falls within the scope of article ${ }_{51} \mathrm{CFR}$ and is therefore subject to scrutiny by the Court. The CJEU invalidates the amendments of its laws (restriction of access to court) imposed on Luxembourg by the Global Forum. It needs to be seen whether the ECtHR will also provide protection to the concerned party in an exchange of information on the basis of a bilateral tax convention. The presumption of mutual trust, which restricts the review of the facts by a court in EU settings, does not exist outside the area of Freedom, Security and Justice. That requires a more in-depth review by a court, of facts and legality. Positive law is lacking and the Standard for EOIR does not provide for legal protection of taxpayers in transnational or international exchange of information procedures. General principles of law should replace positive law deficiencies. European parties are reasonably protected in a transnational setting, but serious doubts exist with respect to the rights of concerned parties outside the European area.

81 See CJEU decision 21-12-2011 (Joined Cases C-411/10 and C-493/10) (N.S. v. Secretary of State for the Home Department), pt. 100 considered in ECtHR decision 16-5-2016 (Avontis), case 17502/07, pt. 46.

82 See ECtHR decision 30-6-2005 (Bosphorus), case 45036/98: 156. If such equivalent protection is considered to be provided by the organisation, the presumption will be that a State has not departed from the requirements of the Convention when it does no more than implement legal obligations flowing from its membership of the organisation. However, any such presumption can be rebutted if, in the circumstances of a particular case, it is considered that the protection of Convention rights was manifestly deficient. In its judgement on Avotins v. Latvia (23-5-2016, appli.no. 17502/O7) the ECtHR revisited the Bosphorus-judgement. 